\title{
Fluorescence Sensors for Lithium lons and Small Peptides
}

\author{
Sébastien Rochat ${ }^{\S}$ and Kay Severin \\ §SCS Mettler-Toledo Award Winner (Oral Presentation)
}

\begin{abstract}
Simple but powerful chemosensors were developed by taking advantage of self-assembly processes. First, we will describe a turn-on fluorescent sensor for the pharmacologically important lithium ion. The sensor can be used in purely aqueous solution, and it displays a very high selectivity for lithium over sodium and magnesium ions. It is based on a metallacrown receptor unit, which can be assembled in situ from simple building blocks. Furthermore, we will describe a cross-reactive sensor array for the detection of small peptides. The individual sensors of the array are formed by mixing metal complexes with fluorescent dyes.
\end{abstract}

Keywords: Fluorescence spectroscopy · Indicator displacement assay · Lithium · Peptide · Sensor

\section{Introduction}

Analyte-selective chemosensors have been investigated extensively by many research groups. Quite often, substantial synthetic efforts are required in order to achieve good sensitivity and selectivity. In this article, we present two types of sensors, which overcome synthetic difficulties by using self-assembly processes. First, we describe a selective turn-on fluorescent sensor for lithium ions in water. Second, we present a sensor array for peptides. The array was made by simply mixing commercially available fluorescent dyes and metal complexes.

\section{A Turn-on Fluorescence Sensor for Lithium Ions[1]}

The selective sensing of the pharmacologically important ${ }^{[2]}$ lithium cation in aqueous solution is a challenging task. ${ }^{[3,4]}$ Due to the high solvation energy of $\mathrm{Li}^{+}, \mathrm{a}$ very potent ionophore is required in order to capture it. Furthermore, $\mathrm{Li}^{+}$is usually
${ }^{*}$ Correspondence: S. Rochat

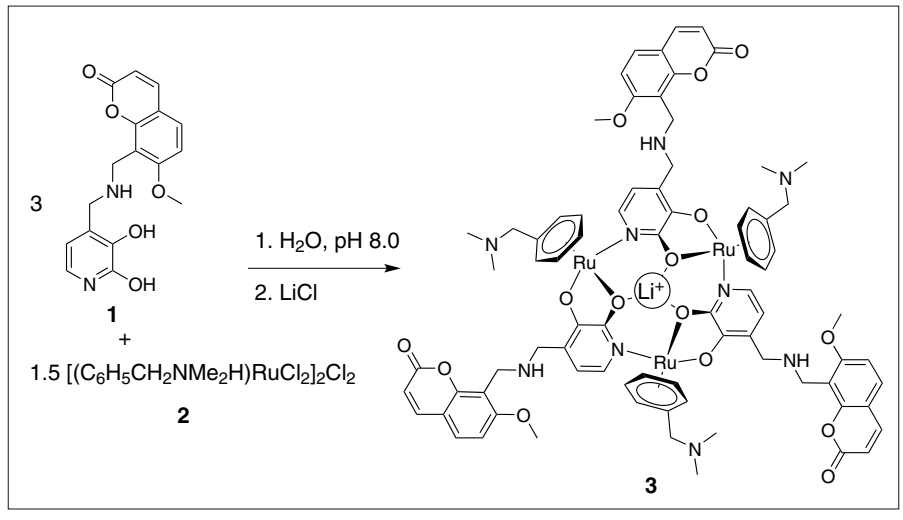

Scheme 1. Selfassembly of the lithium sensor $\mathbf{3}$ (shown in its deprotonated form), and $\mathrm{Li}^{+}$uptake at the binding site. found in the presence of high concentrations of competing ions such as $\mathrm{Na}^{+}$or $\mathrm{K}^{+}$. A chemosensor therefore needs to display a very good selectivity.

Over the past years, we and others have investigated extensively the chemistry of 12-metallacrown-3 complexes..$^{[5,6]}$ These macrocycles can be obtained by reaction of organometallic half-sandwich complexes of $\mathrm{Ru}(\mathrm{II}), \mathrm{Rh}(\mathrm{III})$, or Ir(III) with organic ligands containing the 2,3-dihydroxypyridine motif. 12-Metallacrown-3 complexes of this kind were found to have a pronounced affinity for $\mathrm{Li}^{+}$and a good selectivity over other cations. Furthermore, simple modifications of the organic ligands made these complexes water soluble. ${ }^{[6 \mathrm{~d}, \mathrm{f}]}$

As the recognition unit for our $\mathrm{Li}^{+}$sensor, we employed a 12-metallacrown-3 complex that was decorated with fluorescent dyes. The fluorophore 7-methoxycoumarin was appended to 2,3-dihydroxypyridine to afford ligand 1 (Scheme 1). Base-assisted self-assembly of $\mathbf{1}$ and the arene ruthenium chloro-dimer $\left[\left(\mathrm{C}_{6} \mathrm{H}_{5}\right.\right.$ $\left.\left.\mathrm{CH}_{2} \mathrm{NMe}_{2} \mathrm{H}\right) \mathrm{RuCl}_{2}\right]_{2} \mathrm{Cl}_{2}$ (2) afforded the 12-metallacrown-3 complex 3 . Thanks to its numerous amine groups, macrocycle $\mathbf{3}$ was found to be soluble in buffered water ( $\mathrm{pH}$ 8.0, phosphate buffer). Interestingly, the synthesis of complex 3 can be performed in situ: all that is required is to mix the building blocks $\mathbf{1}$ and $\mathbf{2}$ in a 2:1 ratio in buffered aqueous solution; complex $\mathbf{3}$ is then formed by self-assembly in nearly quantitative yield (Scheme 1).

It was observed that the fluorescence intensity of ligand $\mathbf{1}$ was strongly reduced by formation of macrocycle 3 . This reduction was an expected effect, since the $\mathrm{Ru}(\mathrm{II})$ centers are able to quench the fluorescence by electron transfer. Upon complexation of $\mathrm{Li}^{+}, \mathrm{Ru}$-based 12-metallacrown-3 complexes are more difficult to oxidize, ${ }^{[6 \mathrm{k}, \mathrm{j}]}$ and electron transfer is thus less effective. Consequently, an increase of the fluorescence intensity was observed when $\mathrm{Li}^{+}$was present in the solution. An association constant of $K_{(\mathrm{a}}\left(\mathrm{Li}^{+}\right)=7.4( \pm 0.6)$ $10^{2} \mathrm{M}^{-1}$ was determined by fluorescence titration experiments. This affinity was sufficient for the detection of lithium ions in the low millimolar concentration range 
(Fig. 1). The sensor displayed a very good selectivity: even in the presence of a large excess of $\mathrm{Na}^{+}$(up to $140 \mathrm{mM}$ ), a minimal increase in fluorescence was observed (less than $15 \%$ ). The addition of $\mathrm{K}^{+}, \mathrm{Ca}^{2+}$, or $\mathrm{Mg}^{2+}$ gave negligible changes in fluorescence. The sensor 3 could also be used to detect lithium in a more complex matrix as evidenced by $\mathrm{Li}^{+}$sensing experiments in deproteinized human serum (Fig. 1).

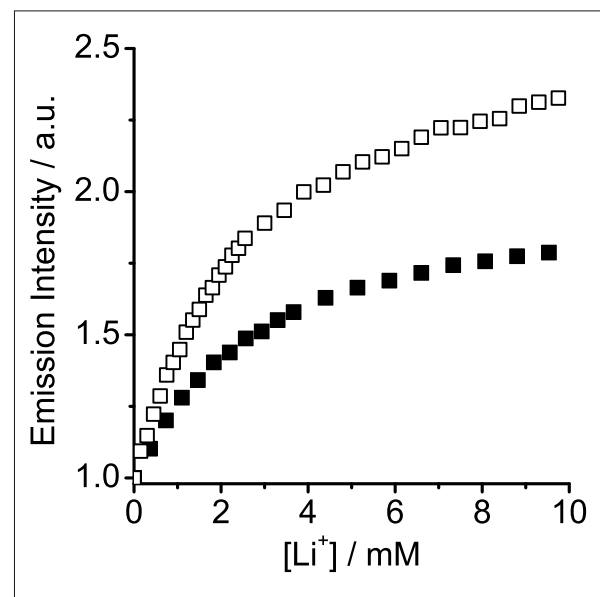

Fig. 1. Emission intensity at $480 \mathrm{~nm}$ (excitation at $382 \mathrm{~nm}$ ) for solutions containing complex $3(2.0 \mathrm{mM})$ and variable concentrations of $\mathrm{LiCl}$. The data labeled with $\mathbf{q}$ were obtained in water ( $\mathrm{pH} 8.0$, phosphate buffer), whereas the data labeled with $\square$ were obtained in deproteinized serum.

\section{Sensor Arrays for the Detection of Small Peptides[7]}

The pattern-based recognition of bioanalytes in solution represents an interesting alternative to classical, target-selective chemosensors. ${ }^{[8,9]}$ We have developed a sensor array, which allows the detection of small peptides at low micromolar concentrations. ${ }^{[7]}$ The basic principle of our array is shown in Fig. 2. In each sensor, the peptide analyte and a fluorescent dye compete for the complexation to a metal complex ' $\mathrm{M}$ '. Upon complexation to the metal, the fluorescence of the dye is quenched. The fluorescence intensity of the mixture can thus be correlated to the relative stability of the metal-dye and the metal-analyte complex. The array is composed of sensors with different dyes and metal complexes (shown in Fig. 2 is a minimal array with two dyes and two metal complexes). Each metal-dye combination is expected to give a slightly different response. Analysis of the overall response of the sensor array by pattern recognition protocols allows the analyte(s) to be identified.

For the construction of our array, we used three metal complexes ( $\left[\mathrm{RhCl}_{2} \mathrm{Cp}^{*}\right]_{2}$,

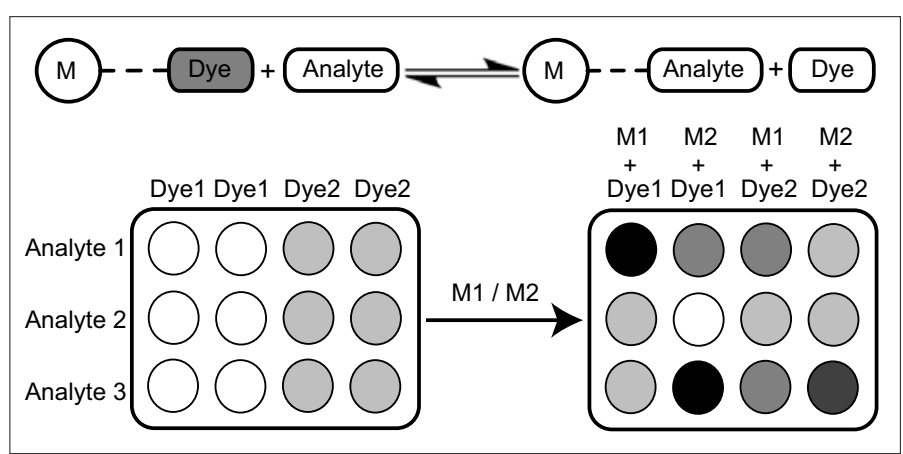

Fig. 2. Basic principle of a sensor array based on competition reactions of analytes and metal-dye complexes.

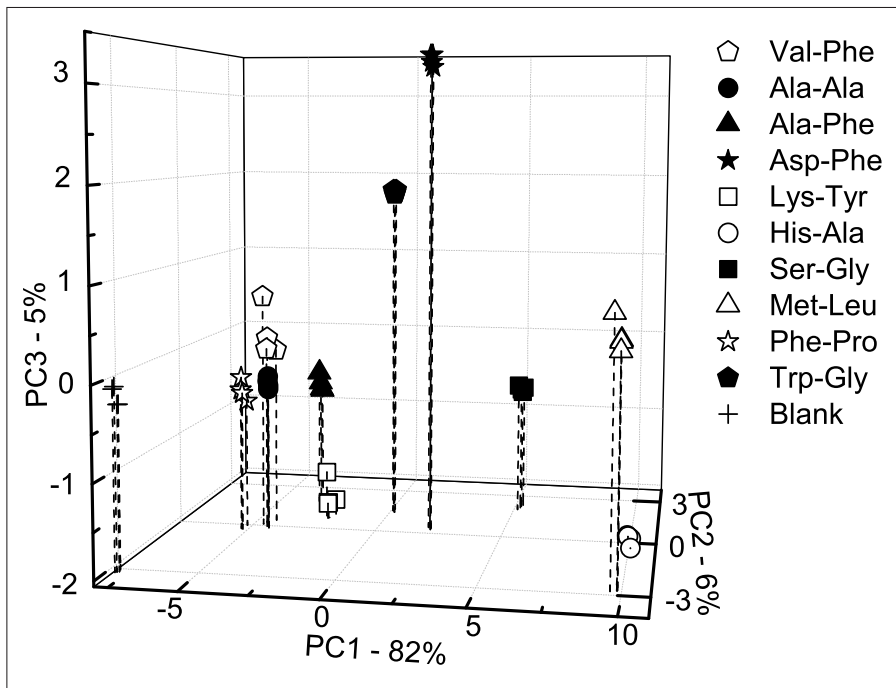

Fig. 3. A threedimensional PCA score plot showing clustering and separation of the dipeptide analytes at a concentration of 50 $\mu \mathrm{M}$.

$\left[\mathrm{RuCl}_{2}(p \text {-cymene })\right]_{2}$, and $\left.\left[\mathrm{PdCl}_{2}(\mathrm{en})\right]\right)$, and six fluorescent dyes (methyl calcein blue, calcein blue, calcein, nuclear fast red, N-methylanthranilic acid, and lumazine). The metal complexes were chosen because they are soluble and stable in water (even in the presence of air), they are able to quench the fluorescence of the dyes, and they display a high affinity for the peptide analytes. All six dyes show a strong affinity for the metal complexes (the association constants range from $10^{4} \mathrm{M}^{-1}$ to more than $10^{7} \mathrm{M}^{-1}$ ). The assays were performed as follows: buffered aqueous solutions of the respective dye and the peptide were mixed and the competition reaction was then initiated by addition of a solution of the appropriate metal complex. The fluorescence intensity of the individual sensors was measured in a time-resolved fashion at 5, 20, and $60 \mathrm{~min}$. The resulting data was used as input for a pattern recognition analysis. We found that our system was able to differentiate ten dipeptides at a concentration of $50 \mu \mathrm{M}$ with high accuracy. Depicted in Fig. 3 is a graphic representation of the results of a principal component analysis (PCA). ${ }^{[10]}$ The experiments were performed in quadruplicate, and one can observe a good separation of the clusters representing the different peptide samples. Interestingly, the value of the first principal component (PC1) is correlated with the affinity of the peptide for the metal receptor. The weakly coordinating dipeptide Phe-Pro has a low value (PC1 = $-5.22(0.05))$ close to that of a blank sample without peptide $(\mathrm{PC} 1=-7.86(0.06))$, whereas the peptides containing strongly coordinating His or Met residues appear with the highest values (His-Ala: PC1 = 10.00(0.06); Met-Leu: PC1 = 9.78(0.12)). The statistical analysis permitted us to determine which metal-dye combinations of our array were the most useful for the discrimination of the dipeptides. Some of the sensors were found to be less important and a reduced version of the sensor array with only six metal-dye combinations still gave a perfect discrimination of the ten dipeptides.

We have also investigated whether our reduced sensor array was able to work in a complex matrix such as deproteinized human serum. As analytes, we chose carnosine ( $\beta$-alanyl-histidine) and homocarnosine ( $\gamma$-aminobutyryl-histidine). The presence of these two very similar dipeptides in human blood is usually attributed to genetic disorders. ${ }^{[11]}$ Different quantities of the dipeptides $(0-100 \mu \mathrm{M})$ were mixed with serum solutions containing the respective metal-dye combination. The fluorescence response was then recorded in a time-resolved fashion and the obtained data were used as the input for a PCA. The resulting score plot revealed that the 


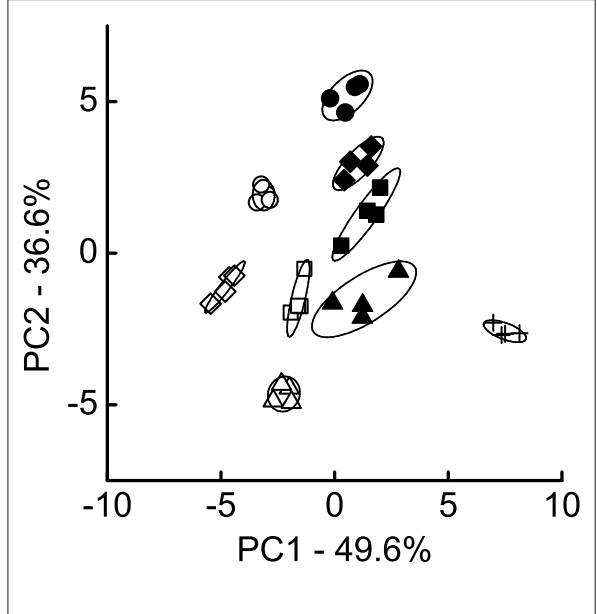

Fig. 4. PCA score plot showing clustering and separation of serum solutions containing different concentrations of carnosine $(C$, filled symbols) and homocarnosine (HC, open symbols) at different concentrations: $25 \mu \mathrm{M}$ (triangle), $50 \mu \mathrm{M}$ (square), $75 \mu \mathrm{M}$ (rhombus) and $100 \mu \mathrm{M}$ (circle). The blank samples without peptide are represented by +

sensor array was able to distinguish carnosine from homocarnosine and to obtain information about the concentration of the dipeptide sample (Fig. 4).

Finally, we have demonstrated that the sensor array can be used to analyze mixtures of the nonapeptide bradykinin (BK) and decapeptide kallidin (Lys-bradykinin, KD). Six metal-dye combinations were found to be sufficient to discriminate solutions containing various ratios of $\mathrm{KD}$ and BK (Fig. 5).

\section{Conclusions}

In the first part of this article we have described a very selective chemosensor for lithium ions. ${ }^{[1]}$ The sensor can be obtained by self-assembly of a Ru(II) half-sandwich complex and a modified 2,3-dihydroxypyridine ligand. It acts as a fluorescence turn-on sensor, allowing the detection of lithium ions in the low millimolar concentration range, even in the presence of competing ions such as $\mathrm{Na}^{+}$. In the second part of the article we have described cross-reactive sensor arrays, which can be constructed from commercially available fluorescent dyes and simple transition metal complexes. ${ }^{[7]}$ The sensors display a remarkable analytical power: samples containing low-micromolar concentrations of dipeptides can be identified with high accuracy, and mixtures of the nonapeptide bradykinin and the decapeptide kallidin can be distinguished. Furthermore, the sensor can be used to obtain information about the identity and the quantity of the pharmacologically interesting dipeptides

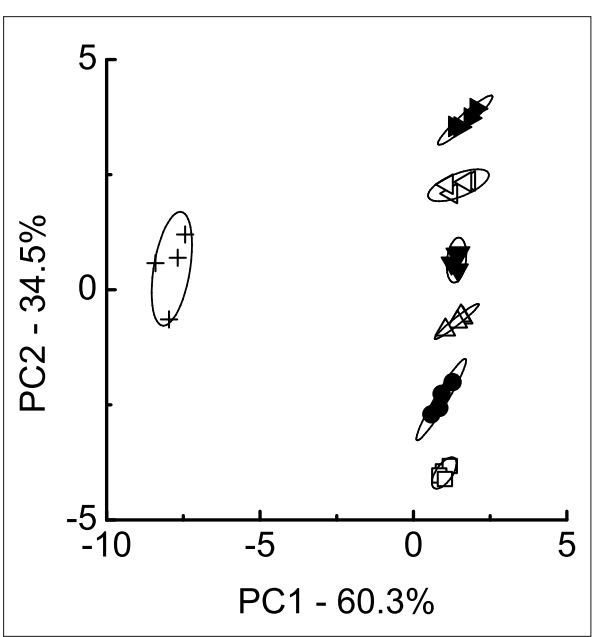

Fig. 5. PCA score plot showing clustering and separation of different mixtures of kallidin $(\mathrm{K})$ and bradykinin (BK). $[\mathrm{BK}]=50-\chi \mu \mathrm{M},[\mathrm{KD}]=$ $\chi \mu \mathrm{M} ; \chi=0(\triangleright), 10(\triangleleft), 20(\nabla), 30(\triangle), 40(\bullet)$, and $50(\square)$. The blank samples without peptide are represented by + .

carnosine and homocarnosine in a complex biological matrix.

Received: January 15, 2010

[1] S. Rochat, Z. Grote, K. Severin, Org. Biomol. Chem. 2009, 7, 1147.

[2] a) D. M. De Freitas, M. M. C. A. Castro, C. F. G. C. Geraldes Acc. Chem. Res. 2006, 39, 283; b) N. J. Birch, Chem. Rev. 1999, 99, 2659.

[3] a) R. A. Bartsch, V. Ramesh, R. O. Bach, T. Shono, K. Kimura, in 'Lithium Chemistry: A Theoretical and Experimental Overview', Eds. A.-M. Sapse, P. von Ragué Schleyer, Wiley, New York, 1995, p. 393; b) K. Kobiro, Coord. Chem. Rev. 1996, 148, 135.

[4] Selected examples: a) D. Citterio, J. Takeda, M. Kosugi, H. Hisamoto, S.-i. Sasaki, H. Komatsu, K. Suzuki, Anal. Chem. 2007, 79, 1237; b) W. Liu, J.-H. Lu, Y. Ji, J.-L. Zuo, X.Z. You, Tetrahedron Lett. 2006, 47, 3431; c) A. Caballero, R. Tormos, A. Espinosa, M. D. Velasco, A. Tárraga, M. A. Miranda, P. Molina, Org. Lett. 2004, 6, 4599.

[5] a) T. B. Rauchfuss, K. Severin, in 'Organic Nanostructures', Eds. J. L. Atwood, J. W. Steed, Wiley-VCH, Weinheim, 2008, p. 179; b) G. Mezei, C. M. Zaleski, V. L. Pecoraro, Chem. Rev. 2007, 107, 4933; c) K. Severin, Chem. Commun. 2006, 3859; d) K. Severin, Coord. Chem. Rev. 2003, 245, 3.

[6] a) S. Katsuta, T. Imoto, Y. Kudo, Y. Takeda, Anal. Sci. 2008, 24, 1215; b) S. Katsuta, Y. Iwabe, Y. Kato, Y. Kudo, Y. Takeda, Inorg. Chim. Acta 2008, 361, 103; c) L. Mimassi, C. Cordier, C. Guyard-Duhayon, B. E. Mann, H. Amouri, Organometallics 2007, 26, 860; d) Z. Grote, R. Scopelliti, K. Severin J. Am. Chem. Soc. 2004, 126, 16959; e) L. Mimassi, C. Guyard-Duhayon, M. N. Rager, H. Amouri, Inorg. Chem. 2004, 43, 6644; f) Z. Grote, M.-L. Lehaire, R. Scopelliti, K. Severin, J. Am. Chem. Soc. 2003, 125, 13638; g) M.-L. Lehaire, A. Schulz, R. Scopelliti, K. Severin, Inorg. Chem. 2003, 42, 3576; h) M.-L. Lehaire, R. Scopelliti, H. Piotrowski, K. Severin, Angew. Chem., Int. Ed. 2002, 41, 1419; i) M.-L. Lehaire, R. Scopelliti, K. Severin, Chem. Commun.
2002, 2766; j) M.-L. Lehaire, R. Scopelliti, K. Severin, Inorg. Chem., 2002, 41, 5466; k) H Piotrowski, K. Severin, Proc. Natl. Acad. Sci. USA 2002, 99, 4997; 1) H. Piotrowski, G. Hilt, A. Schulz, P. Mayer, K. Polborn, K. Severin, Chem. Eur. J. 2001, 7, 3196; m) H. Piotrowski, K. Polborn, G. Hilt, K. Severin, J. Am. Chem. Soc. 2001, 123, 2699

[7] S. Rochat, J. Gao, X. Qian, F. Zaubitzer, K. Severin, Chem. Eur. J. 2010, 16, 104.

[8] a) B. E. Collins, A. T. Wright, E. V. Anslyn, Top. Curr. Chem. 2007, 277, 181; b) S. Otto, K Severin, Top. Curr. Chem. 2007, 277, 267; c) A. T. Wright, E. V. Anslyn, Chem. Soc. Rev. 2006, 35, 14; d) J. J. Lavigne, E. V. Anslyn, Angew. Chem., Int. Ed. 2001, 40, 3118.

[9] Selected examples: a) R. B. C. Jagt, R. F. Gómez-Biagi, M. Nitz, Angew. Chem., Int. Ed. 2009, 48, 1995; b) F. Zaubitzer, T. RiisJohannessen, K. Severin, Org. Biomol. Chem. 2009, 7, 4598; c) D. Margulies, A. D. Hamilton, Angew. Chem., Int. Ed. 2009, 48, 1771; d) E. N. Savariar, S. Ghosh, D. C. González, S. Thayumanavan, J. Am. Chem. Soc. 2008, 130, 5416; e) A. T. Wright, N. Y. Edwards, E. V. Anslyn, J. T. McDevitt, Angew. Chem., Int. Ed. 2007, 46, 8212; f) A. Schiller, R. A. Wessling, B. Singaram, Angew. Chem., Int. Ed. 2007, 46, 6457; g) O. R. Miranda, C.-C. You, R. Phillips, I.-B. Kim, P. S. Ghosh, U. H. F. Bunz, V. M. Rotello, J. Am. Chem. Soc. 2007, 129, 9856; h) F. Zaubitzer, A. Buryak, K. Severin, Chem. Eur J. 2006, 12, 3928; i) A. Buryak, K. Severin, J. Am. Chem. Soc. 2005, 127, 3700; j) A. T. Wright, E. V. Anslyn, J. T. McDevitt, J. Am. Chem. Soc. 2005, 127, 17405.

[10] P. C. Jurs, G. A. Bakken, H. E. McClelland, Chem. Rev. 2000, 100, 2649.

[11] S. M. Willi, Y. Zhang, J. B. Hill, M. C. Phelan, R. C. Michaelis, K. R. Holden, Pediatr. Res. 1997, 41, 210. 